\title{
The African background of the prosperity gospel
}

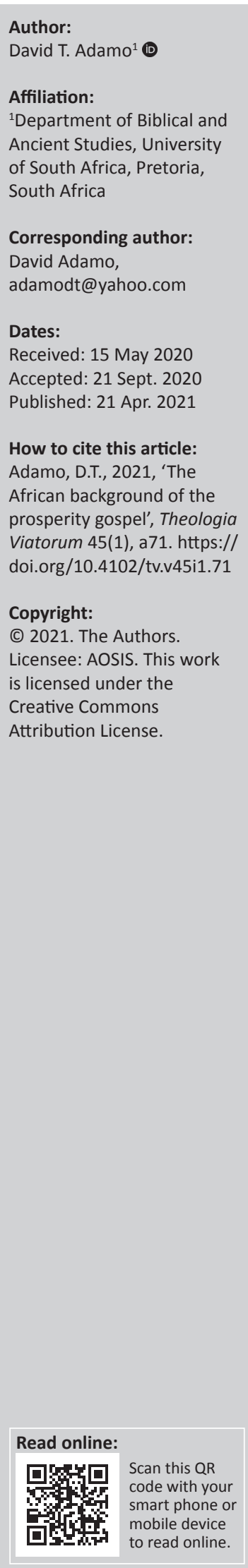

Prosperity gospel refers to the genre of preaching that emphasises positive confession, divine physical healing, divine material success as necessary gifts, and blessing from God. In other words, it is the spiritualisation of materiality and celebration of the abundance, which comes from God as a result of divine promise from him. The prosperity gospel is a form of Pentecostalism. There are three ways in which the background of prosperity gospel can be traced to Africa: (1) African Traditional religious heritage; (2) African social-cultural heritage; and (3) historical heritage. This article seeks to examine these three ways in which the background of prosperity gospel can be traced to Africa. This is supported by the fact that the black culture has not been lost in the lives of the slaves even when languages, family bondages, ethnic belongings were unscrupulously destroyed, and Seymour, an African American, is the father of Pentecostalism, from which prosperity gospel was born.

Keywords: Africa; Yoruba; African traditional religion; prosperity gospel; healing; Pentecostalism.

\section{Introduction}

The prosperity gospel is one of the most misunderstood brands of Christianity (Heuser 2015:16; 2016:3). In other words, the gospel reflects the theology and culture around it (Bowler 2013:12). One of the reasons so many people misunderstand prosperity preachers is the diverse and loose affiliations amongst the preachers and churches (Bowler 2013). It has been branded as a gospel of deceit that is deadly (Piper 2007). It has been labelled as the modern gospel that is marketed to consumers and not proclaimed to penitent sinners (Horton 1990:28). According to Kahl (2007:21), the concepts entailed by prosperity preaching are incompatible with the teachings. Various names have been attributed to prosperity gospel: 'health and wealth gospel', 'gospel of success' (Niemandt 2017:203-219), 'seed faith gospel' and 'capitalist dogma' (Thomas 2012:163-172). It has also been branded as 'Word of faith', 'positive confession', 'prosperity theology', 'the law of reciprocity' (Koch 2009:1; Mumford 2012:1), 'gospel of greed' and 'prosperity lite' (Koch 2009:1). It is also called 'American gospel of pragmatism', 'individualism', 'upward mobility' (Bowler 2013:11), 'commercialized gospel' (Ghotoe 2013:26) and 'another form of Pentecostalism' (Ceser \& Richard 2000:6; Gbotoe \& Kgatla 2014:3).

This article does not intend to get involved in whether prosperity gospel is right or wrong or to do a biblical evaluation of the prosperity and health gospel as many other people have done because theology and interpretation are contextual. For example, prosperity preachers have been criticised by saying that they take the Bible texts out of context to make it say what they want; they stretch and distort the truth, and they teach as doctrines the commandments of men; and their claims are ludicrous and heretical; and their theology is self-centered spiritually (Dada 2001:82-92; Mende 2019:19-35; Niemandt 2017:203-219; Piper 2007 \& others; Thomas 2012:163-172). A claim to the absolute truth of the Bible and its interpretation is doubtful (Adamo 2008:575-592). ${ }^{1}$ One tends to agree with Cox (1992:39-44) that a religious movement that has already encompassed nearly half a million people and is multiplying geometrically should not be outrightly be dismissed because every religious group and denomination has its good and bad side.

Cox (1992:44) also predicted that 'by early next century, Pentecostals in all their varieties (including prosperity gospel preachers) will outnumber both Catholics and Protestants'. According to Hollenweger (1999:33-44), 'Pentecostals (including prosperity gospel) is already

1.A casual glance at the history of biblical interpretation will reveal that there has never been an interpretation that is without reference to or dependent on a particular cultural code, thought patterns or social location of the interpreter (Mulrain 1999: 166-132). No individual who is completely detached from everything in his or her environment or experience and culture to be able to render 100 per cent objectivity in everything done. The fact is that every interpreter is biased in some ways (Mulrain 1999:116-132). Therefore, to talk of uniform, unconditional, universal and absolute interpretation or hermeneutics is unrealistic (Adamo 2008:575-592). 
more important than any denomination in the Protestant world and they are continuing to grow'. According to Hoerschelman (1990:67-70), 'Pentecostal's spirituality is the future'.

The purpose of this article is to argue for the African background of the prosperity gospel base on other findings. To do that, this article attempts to define the various meaning of prosperity gospel according to different scholars, identifies some important African personalities of the prosperity gospel, and discuss the exact ways in which Africa is the background of the prosperity gospel-by way of African Traditional religious heritage, African social-cultural heritage-power of potent words, and historical heritageAfrican root of African American heritage.

\section{Definition of prosperity gospel}

Because the term prosperity gospel is not a monolithic theological system, any attempt to define it is bound to face the risk of distortion or oversimplification according to Burgess (ed. 2006:393). To minimise such risk it is important to refer to some important sources that relate to Pentecostal and charismatic Christianity.

According to Oxford Advanced Learner's Dictionary, prosperity is 'the state of being successful, especially in the accumulation of wealth' (Tumbull 2010:2331). According to The Encyclopaedia of Pentecostal and Charismatic Christianity, the prosperity gospel is:

Christian worldviews that emphasize an earthly life of health, wealth, and happiness as the divine, inalienable right of all who have faith in God and live in obedience to His commands. (ed. Burgess 2006:393)

The African chapter Lausanne Theology Working Group defines the prosperity gospel as:

$[T]$ he teaching that believers have a right to blessings of health and wealth and that they can obtain these blessings through positive confessions of faith and the sowing of seeds through the faithful payments of tithes and offerings. (viewed 03 May 2020, from http://www.lausanne.org/en/documents/all/twg/1099a-statement-on-the-prosperity gospel.html) ${ }^{2}$

\section{Gifford (1998) also defines Prosperity as:}

... [T] he faith gospel, God has met all the needs of human beings in suffering and death of Christ and every Christian should now share the victory of Christ over sin, sickness, and poverty. A believer has the right to the blessings of health and wealth won by Christ and he/she can obtain these blessings merely by a positive confession of faith. (p. 62)

The prosperity gospel preachers claim that through the power of visualisation, power of minds and power of imagination, Christians can bring to reality their needs by faith (Gbote \& Kgatla 2014:1-14).

2.One also appreciates the call of Atibaia Lausanne's statement for a call to confession action, ethics and wealth, generosity and blessings, justice and shalom, healing and
compassion, and building of a relationship (https://www.lausanne.org/content/ compassion, and building of a relatior
statement/atibaia-statement, 1-10).
According to Asamoah-Gyadu (2005):

The underlying theory of the gospel of prosperity is that God rewards faithful Christians with good health, financial success, and material wealth, according to his glorious riches in Christ Jesus (Philippians 4:19). (p. 202)

Westerlund's (2009:1) definition is similar to AsamoahGyadu when he says that prosperity gospel concerns itself primarily with the work of the Holy Spirit and the practice of spiritual gifts. According to Coleman (2000:77), prosperity is the accumulation of wealth and good health based on one's good work and the grace given by God. Westerlund's definition of the prosperity gospel is also interesting and instructive (Westerlund 2009:1). Magezi and Manzanga (2016:4-5) listed what they consider to be the tenet of the prosperity gospel: faith, positive confession, seed faith principle and the deification of man as a 'little god'.

Niemandt (2017:203-219) defines prosperity gospel as the spiritualisation of materiality and the celebration of the classic symbol of surplus or excess and consumerism. He goes further to see prosperity gospel as 'a new form of colonialisation' (2017:203-219) because of the emphasis on the material blessing, which represents the new form of the Pentecostalism with certain phrases common to them: 'sowing and reaping, naming and claiming it to create a world of reality in faith'. The movement preaches that God has empowered them to help believers get out of their liability and meet their financial needs (Niemandt 2017:203-219).

The prosperity gospel is considered another form of Pentecostalism (Hollenweger 1999:33-44; Westerlund 2009:1). ${ }^{3}$ Pentecostalism according to Westerlund is a renewal movement within Christianity that places special emphasis on direct personal experience with God through the baptism of the Holy Spirit (2009:1).

According to Koch, the prosperity gospel preachers are poor because of lack of faith, and poverty is the fault of the poor people themselves because God is very interested in the affairs of the believers' financial status (Koch 2009:1). Christians should, therefore, deal with the faith of the poor, and not poverty (Koch 2009:1). The prosperity gospel is another form of Pentecostalism (Gbotoe \& Kgatla 2014:3).

Like the African priests of African Traditional Religion (ATR), the prosperity gospel preachers claim to have the ammunition and the necessary weapons to protect and deliver believers from all evil attacks (Jenkins 2006:104-106).

The above definitions appear interesting because some are negative and others are positive. For example, calling prosperity gospel 'capital dogma', 'the gospel of greed' and 'commercialized gospel' reflects critic's bias towards prosperity gospel. It seems they cannot see anything good in prosperity preaching. However, Weserlund's, Asamoah's,

3.It should not be misunderstood that it means prosperity gospel is equal to Pentecostalism because there are Pentecostals who are not prosperity gospel preachers. Some Pentecostals do distance themselves from prosperity preachers. 
Mumford's, Bowler's definitions are positive, wheras others like Coleman's, Piper's, Gbote's, Kahl's and Thomas' are negative as mentioned above.

\section{Brief survey of some important personalities of prosperity preachers}

The prosperity gospel has spread throughout the world in different forms. It can be found in West and Southern Africa, North and South America, South Korea and Europe in different forms (Coleman 2000:76). ${ }^{4}$ The following are some prosperity preachers: Kenneth Hagin, Kenneth Copeland, Oral Roberts (USA), Matthew Ashimolowo (London), J. D Salinas (Latin America), K Shyan Kishore and Samuel Patta (India), David Oyedepo and Benson Idahosa (Nigeria), Keneth Mbugua (Nairobi), S Bushiri and Mboro Bio (South Africa), E. Makandiwa (Zimbabwe), A. Bugingo (Democratic Republic of Congo) and others.

Oral Roberts was the first person to formulate prosperity gospel into a divine doctrine (Koch 2009:6). As early as 1954, he was teaching his followers to expect a seven-fold return from their contributions to his ministry (Harrell 1975). Oral Roberts is one of the key figures of prosperity gospel preaching with his 'seed faith theology'. He popularised the notion of 'The divine economy', which is an economic system that believes that God wants to provide believers with material prosperity. His divine economy can be activated through faith in God and the law of sowing and reaping or seed-faith. The law of seed-faith is based on three main principles. (1) Believers should turn their lives completely to God and recognise that God is the source of all their needs and if they bless any one person, they are not the source of the blessing but God. (2) The principle of sowing and reaping: according to him, whatever any believer gives freely to God will be returned to him or her in many folds.

(3) The seed of anything, such as compassion, talent, time, love, money and kindness, will be received back from God (Roberts 1970:37).

Kenneth Hagin is considered the father of prosperity preaching in America (Barron 1987; Bruce 1990; Hollinger 1991). He was born a sickly child in 1917 and went to school in McKinney, Texas. Soon after his divine healing, he started preaching (Mumford 2012:365-379). He encouraged his followers not only to hope to receive the prosperity and healing that God promised in the Bible but that they have received them already. Hagin later moved to Oklahoma and found Kenneth E. Hagin Evangelistic Association with a 'Word of Faith' magazine, thus establishing the Word of Faith Movement (Mumford 2012:365-379). In addition to his belief in divine healing and new thought he also introduced Pentecostalism in the Word of Faith Movement. Kenneth Hagin's Word-Faith theology has two major components: divine healing and God's desire to materially bless believers. He played a key role in the expansion of prosperity theology (Olusuyi 2017:9).
Joel Osteen denies that he is a prosperity preacher because he has never preached a sermon about money (King 2006). He said, 'I don't think I've ever preached a sermon about money' (Van Biema \& Chu 2006:53). However, he has a book with a title, Your best life now: 7 steps to living at Your Full Potential, and with these words, 'God wants to increase you financially ...' (Osteen 2004:5):

$[A]$ nd the only place in the Bible (Malachi 3:12) where God tells us to prove Him ... which means to test Him or check Him out-is in the area of our finance. (p. 257)

According to him, if you take a step of faith and honour God in your tithe he will begin to increase your supply in supernatural ways. 'God will take that 90 percent you have leftover and He'll cause it to go further than the 100 percent with which you started'. According to him (1989:34), he will promote you; he will deliver you from sickness, accidents and unnecessary expenses.

One of the earliest African preachers of the prosperity gospel in Africa was Idahosa (Anderson 2014:66; Kwanteng-Yeboah 2017:17). After his training in Rhema Bible College of Kenneth Hagin he established his own mission, Church of God Mission International where he trained many Nigerians and West African pastors including Archbishop Nicholas Duncan Williams who is the founder of the first Ghanian Pentecostal Church (Anderson 2014:133; Asamoah-Gyadu 2013:64).

Idahosa, a Nigerian, expresses the traditional African perception that wealth and success are a result of God's blessing (Hock 1995:59). He applied the Pentecostal perspective with the authority to heal and to drive away evil spirits of witchcraft and wizard. His belief in African traditional perception that wealth and success are as a result of God's blessing is what he reformed into prosperity gospel (Hock 1995:59). According to Lyons (1987:34), 'Idahosa's theology was not a transplanted version of American Pentecostalism'. It contains a firm belief in the African healing cults and an indigenous Christian tradition which owes its content to West African religious belief (Idahosa 1987:30; Lyons 1987:104; Olusuyi 2017:11).

Oyedepo is also another Nigerian who is a popular prosperity Preacher who founded 'The Living Faith World Outreach' or Winners Chapel in Lagos in 1983 (Kwanteng-Yeboah 2017:17). Within 16 years his church spread like a wildfire to 38 African countries with the motto of the church, 'I am a winner' (ed. Clarke 2006:5). According to Oyedepo, that 'motto gives you an identity ... it gives you a sense of conviction, that you are heading for something positive' (Kwanteng-Yeboah 2017:17; Maier 2000:264).

Oyedepo believes and preaches that the Abrahamic covenant of blessing is equally appropriate to Christians today. According to Oyedepo, as an ambassador of heaven here on earth, Christians are to enjoy heavenly supplies and provisions, immunity from lack, and want (Oyedepo 2006:40). Oyedepo, basing his argument on 2 Corinthians 8:9, linked 
his message of prosperity to the message of salvation. He thus sees salvation as a means to wealth or deliverance from economic poverty (Oyedepo 2006:74).

Most of the Nigerian and the Ghanian preachers of the prosperity gospel, such as Benson Idahosa, David Oyedepo and Otabil, incorporate African worldview into their preaching of prosperity gospel because African religion and tradition are meant to ensure that the adherents have the blessing of fertility, abundance and longevity, wealth and success which are considered as signs of supernatural blessing from God through the divinities (Kwateng-Yeboa 2017:17-120). In Africa, there is no separation between the sacred and the profane (Du Toit 2009:109). There is a spiritual cause for everything that happens (Du Toit 2009:109). Chilongani says, 'African religion is meant to ensure fertility, abundance and longevity, wealth, and success, and are perceived as signs of supernatural blessing (Chilongani2007:53).

\section{African background of prosperity gospel}

To understand the African background of the prosperity gospel, it is important to discuss the nature of the African worldview and the ATR, and culture briefly. What is a worldview? According to Chidester and Du Toit (Du Toit 1989:16, 20; Chidester 2009:106), worldview is not simply 'a way of seeing or thinking but a multidimensional network of strategies of negotiating person and place in a world of discourse, practice, and association'. African worldview means a totality of what it means to be human of which religion and culture take a greater aspect. In the African worldview nothing happens without spiritual cause because whatever happens on earth is related to whatever happens in the spiritual invisible world (Nel 2019:1-10). It means a belief in a Supreme Being (God), divinities, spirits, ancestors and the practice of magic and medicine. Kruger et al. (2009:36) name three categories in the spirit world of ATR - 'ancestral spirits, nature spirits, and deities'. Though there is no clearcut distinction between spirits and gods, some differences exist. Whilst spirits roam around the earth gods are closer to the Supreme Being with a wider sphere of influence and activity with some divine characteristics (Beyers 2010:1-19). According to Turaki (1999:124), life is always understood spiritually and important questions in life revolve around the spiritual and not the physical. 'Moral principles in African worldview is the pursuit of cosmic harmony, the pursuit of spiritual meaning, the pursuit of mystical powers, and the pursuit of kinship community' (Turaki 1999:122).

Shona worldview has a three-tier structure that is closely linked together, the spiritual world, the human world and the natural world (Sipeyiye 2015:128). Whilst the natural world provides a place for the spirits and sends messages from the spiritual world to the human world, the spiritual world provides guidance, blessing and punishment to the human world (Sipeyiye 2015:128) as the prosperity preachers believe that God sends blessings and guardian through the spirits to believers.

\section{African traditional religious heritage}

There is no unanimous agreement amongst scholars concerning whether ATR as a title should be in the singular or plural. Because each ethnic group in the continent of Africa has her own religion without a single creed or orthodoxy that makes it possible to easily summarise all the belief systems into one, some scholars believe that it should be called ATR in the plural (Beyers 2010:1-19; Kruger, Lubbe \& Steyn 2009:35; Mbiti 1990:1-3; Sipeyiye 2015:127). However, other scholars believe that because there are many fundamental similarities in the structure of ATR generally, it is better to talk of these many African religions as ATR in the singular (Kruger et al. 2009:35). Mbiti later changed his mind. According to Mbiti, even though there is much diversity of religious expressions and multiple identities in Africa as Malueke says (2001:3), the philosophy underlying religious life is singular. ${ }^{5}$ According to Kruger et al. 'religions of Black Africa are similar enough to talk of African Religion in a generic sense. They also share a sufficient number of characteristics' (Kruger et al. 2009:35). According to Magesa, despite the different thoughts of expressions, they remain as one belief (2002:17).

According to ATR, the Supreme Being (God) is the first and the highest in the hierarchy. The Supreme Being revealed himself to every ethnic group in every generation at some point in history (Idowu 1991:140). According to Idowu, before the arrival of missionaries, Africans knew God and called him by various names (Idowu 1991:140). That is why every ethnic group has a local name for God. For example, Yoruba people named him Olodumare. Igbo called him Chukwu. Whilst the Ashanti of Ghana calls him Nyame, the Mende of Sierra Leone calls him Ngewo (Adamo 1983:62). Whist the Zambian calls him Leza, the Zulu of South Africa calls him Nnkuhinkulu (Idowu 1991:150). To express their knowledge of God people all over Africa bear theophoric proper names that are further evidences that God is real to Africans. Such names are Ebere Chukwu-God's mercy (Igbo), Gatkworth-Son of God (Nuer). Mawunyo-God is just or God is kind (Ewe) (Idowu 1991:150). Apart from these names, Africans are very rich in God's attributes signifying to them that God is real and a living one who is ever-active, ever-present. Mbiti lists and discusses the intrinsic attributes of God: Omniscience, omnipresence, Omnipotence, Transcendence and immanence; eternal attribute of God as self-existence, pre-existence, Alpha and Omega, Spirit, invisibility, incomprehensibility and misery, eternity, infinity, immutability, unity and plurality; moral attributes as pity, mercy and kindness, love, comfort, faithfulness, goodness, anger, justice, righteousness and holiness and others (1979:xiii). According to him, although the Akan people refer to God as 'He who knows all', the Zulu and Banyarwanda refers to him as the Wise One (Mbiti 1979:3). The Bacongo usually say 'God knows all', the Barundi refer to God as the Watcher of everything and the

5.Although Mbiti said that it should be plural at first (ATRs) in the first edition of his book African Religion and Philosophy, he later changed his mind for the use of AT in the singular in the preface of the second edition of the same book (1990:3-5). 
Yoruba refers to him as Arinurode Olumoranokan: meaning the one who sees the inside and outside the heart of man (Mbiti 1979:3). Amongst the Shona and Ndebele people the same one God is conceived in the form of the trinity that is as 'Father, Son, and Mother' (Mbiti 1979:30). Before the arrival of Christianity, fertility, health and plenty to Africans, according to the Chagga, are a result of God's blessing and this is recognised by making a sacrifice and reciting prayers of thanks (Mbiti 1979:33). Whilst the Chagga believe that a person cannot be healed unless God permits it, the Herero also believes that any recovery from any illness is from God (Mbiti 1979:69).

\section{Divinities}

Africans believe that God created some beings referred to as divinities. In many African countries, these divinities are innumerable. For example, the Yoruba people have more than 1700 divinities (Mbiti 1979:120; Awolalu 1979:19-20). Because it is impossible to discuss all of them in this article, only a few of them who are venerated for power, healing and prosperity will be discussed to demonstrate that prosperity preaching is not strange to the African Diaspora who was captured as slaves and forced across North America from where Pentecostalism or charismatic or prosperity gospel spread across the world like wildfire. Amongst some societies in Africa the belief that God has delegated power, healing and prosperity to special divinities (Mbiti 1979:64). For example, the Banyoro have a divinity of health, the Basoga has a divinity of healing and the Edo has a divinity of medicine whose assistance is sought during sickness. The Banyarwanda, Burundi, Chagga, Lunda, Yoruba, Ila and possibly others believe that God helps and protects the poor and the weak and gives and takes material wealth through the divinities (Mbiti 1979:83). The Edo has the divinity of wealth, human fertility and the supply of children called Oloku (Mbiti 1979:118).

The Yoruba people of Nigeria seem to have the most numerous divinities (1700) in Africa and the majority of these divinities are worshipped for prosperity, good health, wealth and success (Awolalu 1979:20). Amongst these Yoruba, divinities are Obatala, the first to be created (arch-divinity), and are worshipped for power, prosperity, good health, money and great success (Awolalu 1979:2148; Mbiti 1979:120). Orunmila, the primordial divinity amongst the Yoruba people, has all the wisdom and in charge of pleading for riches, good health, power and blessing for the worshippers (1979:21-28). Osun, the Yoruba goddess of wealth, has power and feminity (Badejo 1996:73-82). She uses her wealth to restore wealth and riches for women.

A close examination of African religion, tradition and culture, especially the religion of the Yorubas, demonstrates that the gods, religion, tradition and culture teach divine prosperity in all dimensions, including good health, money, power and total well-being.

\section{Spirits}

Spirit, as is understood in ATR, is apparitional entities which form a separate category of beings from divinities. Although ancestors have their own spirits, Idowu describes ancestor as domesticated spirits, but the category of spirits we are presently concerned with are often thought of as abstract powers, shades or vapours, which can take human shape but immaterial and incorporeal beings (Idowu 1991:173-174). They can take any form if they wish to be seen. According to African belief, everything has a spirit of its own. Spirit can inhabit any object such as trees, mountains, human beings, rivers, forests, rocks and anything they wish to inhabit or possessed (Idowu 1991:174). Although they may not have names they can be categorised. There are ghost spirits, which refer to the spirits of dead persons who died a sudden death or were not buried properly. Such spirits wander around on earth, living aimlessly on earth. Another category of spirits called abiku in Yoruba language ogbanje in Igbo. Abiku means 'born to die'. Other spirits that Africans have to reckon with painfully are spirits of witches. ${ }^{6}$ There are also guardian-spirits, which sometimes called men's double (Idowu 1991:177). The guardian spirits mean men's spiritual counterparts who guide individual steps. Such spirits can guard an individual through the path of riches. Such can guide an individual towards the path of healing from diseases. They can protect and deliver individual from evil events (Idowu 1991:177).

\section{Ancestors}

One important divinity venerated throughout Africa is an ancestor. Belief in an ancestor is central to ATR and it is a very essential pillar of religion practised in Africa (Beyers 2010:1-19; Stinton 2004:133-134). According to Talbot, no one can hope to appreciate the thoughts and feelings of the black man who does not realise that to him the dead are not dead but living (Talbot 1926:298). They are sacred and have powers. There is a natural and special relationship between the ancestors and earthly descendants (Beyers 2010:1-19). The ancestors do not only have natural relationships with the earthly descendants, but they also have sacred and supernatural status; they are exemplarity; they are companions on the journey of life; and they are mediators and guardians of traditions and symbols of continuity (Beyers 2010:1-19). ${ }^{7}$ The Vugusu believe that the Supreme Being has servants who are the spirits of the dead (ancestors) who acts as guardian of the families and individuals (Mbiti 1979:122). The Igbira people also believe that the departed are God's humble servants. In the Shona view, the spiritual world comprises the tutelary spirit called Mwari, the territorial spirits and the family spirits (Sipeyiye 2015:128).

6.According to Idowu (1991:175), foreigners may deny the existence of witchcraft, but to Africans, it is considered an urgent reality in Africa. Throughout Africa, it is believed that there are guilds of witches that have regular meetings and ceremonies. Africans believe that witches are sadistic ones and known to cause havoc in communities in Africa.

7.The role of ancestors as mediators and guardians of tradition made African Christians see Jesus as the Supreme ancestor (Chidester 2009:107). 
They are called the 'living-dead' (Mbiti 1969:83). They are venerated all over Africa. According to Du Toit, the veneration of ancestors is the best known and most powerful feature of African religion and spirituality', and the ancestor cults have a remarkable uniform structure (2009:107). ${ }^{8}$ Amongst the Yoruba (Awolalu 1979:54) somebody's father after death becomes the most important figure in the spirit world.

The ancestors constitute the closest link between the world of men and the spirit world, and they are believed to be seriously interested in the welfare of their living descendants (Awolalu 1979:63-68; Idowu 1991:178-188). They exercise protective and disciplinary influences on their children (Awolalu 1969:63-68; Idowu 1991:178-188). According to the belief of the Yoruba people, they can be of tremendous benefit for the living family who makes them happy by offering a gift to them (Idowu 1991:178-188). By doing this, all will be well with the living family, including good health, riches and success in life, but if they disobeyed the ancestors, life could be a life of torment (Idowu 1991: 178-188)

According to Gehman, African ancestors usually punish a member of the society for the wrong behaviour and reward them with happiness, wealth, progress and good health if they do well (Gehman 1989:152-154). This argument supports Guma and Milton's observation that the blessings and happiness in human lives are not instantaneous but are the outcome of choices and decisions (1997:65-67).

\section{African social-cultural heritage}

In African social-cultural heritage spoken words are very important, powerful and mysterious amongst the Yoruba people. They are powerful forces. Words have spirit behind them in African. For example, the following are Yoruba tradition's potent words that can prevent diseases, deaths and poverty when they are memorised and recited over and over again (Table 1).

In Table 2 are examples of potent words ofo or ogede to get rich in Yoruba tradition.

Another ofo or ogede that makes one rich by mere pronouncement the way it supposes to be pronounced (Table 3).

Seeking prosperity from God, divinities and ofo has been the practice of Africans from the time immemorial.

It is important to note that Africans who were uprooted from their ancestral land grew up in the above traditional and religious belief in mysterious ways of obtaining riches, power, protection, total good health and success. Because they have been soaked in such a belief, it seldom disappears even after so many years of absence from their ancestral land.
TABLE 1: Yoruba tradition's potent words that can prevent diseases, deaths and poverty.

\begin{tabular}{ll}
\hline Yoruba & English \\
\hline Agogo ide & \\
Orukoti a apeiku & The name we call death \\
Agogo ide- & \\
Orukoti a apeiwonwo & The name we call iwinwo \\
Adilori- & \\
Adilori & Adilori \\
\hline
\end{tabular}

TABLE 2: Potent words to get rich in Yoruba.

\begin{tabular}{ll}
\hline Yoruba & English \\
\hline Ifa ${ }^{9}$ ma jeenmoosi & Ifa, do not let me know poverty \\
Orunmila,,$^{10}$ dakun, ma josi o kan mi & Orunmila, please, do not let poverty be my lot \\
\hline
\end{tabular}

Source: Olatunji, O., 1984, Features of Yoruba oral poetry, p. 164, University Press Limited, Ibadan.

TABLE 3: Potent words to make one rich by mere pronouncement in Yoruba.

\begin{tabular}{ll}
\hline Yoruba & English \\
\hline Nwonni n oolaje & They say I will have riches \\
Nwonni n oolaya & They say I will have wives \\
Nwonni n oolaso & They say I will have clothes \\
\hline
\end{tabular}

Source: Olatunji, O., 1984, Features of Yoruba oral poetry, p. 164, University Press Limited, Ibadan.

In other words, languages, family bonds, names and other things may be destroyed from the African Diaspora, but the element of African religious and cultural background heritage never disappear from them. That is probably the reason why a black man was the founder of Pentecostalism and prosperity gospel in 1906 in America as will be discussed below (Cerillo 1977:10; Hollenweger 1999:31-44; Oliver 1999:44-47).

\section{African historical heritage}

The history of prosperity gospel cannot be truly or correctly be interpreted without the insight and attending reality of oppression, suffering and the history of colonialism by which millions of Africans became enslaved or dehumanised in the name of Christian nation' (Gerloff 1999:67-86).

The forceful removal of ancient Africans as slaves to other continents can be dated back to the classical antiquity (Wood 1999:19). By the 15th and 16th centuries, the Spaniards, the Portuguese, the Dutch, the English and the French were the main slave traders of Africans. The Portuguese explorer first arrived to trade in gold and spices at the Island of Sao Tome. When the Portuguese discovered that the Island was good for growing sugar cane they started using the native Africans for cultivation (Adamo 2015:89-111). By the 1700s more than 100 million Africans were exiled as slaves (Karenga 1983:81). By the 17th to the 18th century, it was estimated that over 12 million Africans more were enslaved and exiled to the New World (Karenga 1983:81).

About 22 million Africans who were taken to America were Christianised and eventually became cross-cultural missionaries (http://www.gosheninti.org/goshen/index. php?option=com_content\&view=article\&id=71\&itemid=77).

9.Ifa is a Yoruba divination that reveals secrets.

10.Orunmila is another Yoruba divination and is the divinity of destiny and prophecy. 
Although the golden age of African American foreign mission was around the 1870s, African American and former slaves were missionaries as early as 1782 (Wilmore 1986:98). Before the official foreign African American missionary society, such persons as David George, Amos Williams and Joseph Paul had struggled to transplant their churches from South Carolina and Georgia in Nova Scotia to Siera Leone, Jamaica and Bahama (Wilmore 1986:98). In 1820, the American Colonization Society (ACS) supported about 88 African Americans who organised an African Methodist congregation and settled them in Liberia. By 1815 when Rev. Lot Carey was asked why he left his own comfortable home in the USA to an unknown danger of Liberia, he replied:

I am an African, and in this country, however meritorious my conduct and respectable my character, I cannot receive the credit due to either. I wish to go to a country where I shall be estimated by my merits, not by my complexion and I feel bound to labour for my suffering race. (Wilmore 1986:99)

After the partition of Africa by the European powers in the 1880s the Congress on Africa, sponsored by Stewart Foundation for Africa, was held in Atlanta, Georgia, 13-15 December 1895, with the theme, 'Africa and the American Negro' (Adamo 2015:89-111).

At the dawn of the 20th-century African American missionaries dominated the African mission field in Africa (Adamo 2015:89-111). The slogan, 'Africa for Africans' and 'Ethiopians stretching forth her hands unto God' (Ps 68:31), was interpreted as not only for 'spiritual salvation alone but also political liberation as well' (Adamo 2015:89-111).

Seymour (1870-1922), a son of a former slave from Africa who lived in Centerville, Louisiana, taught himself to read and write. Seymour as a student of Parham was only allowed to listen to the classroom lectures by standing outside the half-open door in Parham Bible School. ${ }^{11}$ Despite the humiliation and discrimination suffered by Seymour and his black brothers, he went ahead to develop a spirituality that in 1906 led to the revival in Azusa Street, Los Angeles, that most eminent historians believe was the cradle of Pentecostalism from which prosperity gospel comes.

Seymour, one of the former students of Parham, was credited as the father or the founder of Pentecostalism, from which prosperity gospel was born. Seymour therefore started a Pentecostal church where he could freely preach the prosperity gospel. This great revival and the spiritual thirst in Los Angeles started the revival in the Los Angeles' black community at 312 Azuza Street (Cerillo 1977:10). The great manifestation of the power of God and the speaking in tongue at the Azusa Street Revival started on 14 April 1906, as people who came fell and spoke in tongues under the

11.Parham first established a Bible School in Topeka, Kansas, which was originally 'a divine healing home, teaching the justification by faith, the second blessing of sanctification doctrine, divine healing and the second coming of Christ' with only student faith as their tuition fees. power of God. One will be right to say that the origin of the famous Azusa Street Revival, which gave Pentecostalism a global fame, was not Parham's Topeka Revival but William Seymour's (African American) Azusa revival.

Without doubt, the root of Seymour's spirituality (Pentecostalism from which prosperity gospel originates) was from his black African heritage from which he introduced spirituals and music into the liturgy whilst it was considered inferior and unfit for Christian worship. He steadfastly lived practically what he understood to be the meaning of Pentecost (Hollenberger 1999:31-44). According to his theology, Pentecost means more than speaking in tongues, but also means loving the entire nation including those who hate and discriminate (Hollenbeger 1999:31-44). According to Seymour (in Hollenbeger 1999:46-47), God empowered him to bridge the racial gap and integrate Christians of different races, white and black, as one. Seymour's theology was demonstrated in Azuza Street by making Blacks, Mexican, Whites, Asians, men and women to be equal without discrimination (Hollenberger 1999:31-44). Here African spirituality of a sense of a community was demonstrated as his African heritage.

Controversies exist as to who is the founder or father of Pentecostalism (Seymour or Parham?). Although Hollenweger believes very strongly that it must be Seymour, Fatokun thinks it must be Parham (1873-1929) (2007:31-40). However, Seymour is chosen as the Pentecostal root of the Azusa Street Revival and was so acknowledged by the North American Assemblies of God denomination (Richardson 1999:24). Seymour was the first to establish the first Pentecostal church as an autonomous denomination (Oliver 1999:45-47). Without Seymour, the African American preacher, Pentecostalism and prosperity gospel would have remained a local movement (Fatokun 2007:30-40). 'Unquestionably, the growth of Pentecostalism and prosperity gospel should be attributed to its black (African) oral roots' (Oliver 1999:45-47). Seymour, the African American black leader whom God used mightily to lead the Asuza Street Revival in Los Angeles, became the father of Pentecostalism from which prosperity gospel came and not Parham. The Assemblies of God denomination logically and correctly argued in favour of Seymour (Oliver 1999:44-47).

The early Pentecostal from which prosperity gospel movement developed was the contribution of the African scene to the church universal (Gerloff 1999:67-86). The Churches of the Africans in the Diaspora have been the main forerunners of the modern Pentecostal or charismatic movement through the use of the religion and music of the Africans in the New World, which became the two areas in which the slave masters were not able to control or exploit or eradicate. They form the heart of the black church survival in the vibrations of spiritual, cultural and sociopolitical life (Gerloff 1999:67-87). 'Pentecostalism from which prosperity gospel developed on the black scene 
became a contribution of the black heritage' (Gerloff 1999:67-86). 'One is the discovery in black culture and black religion' that the African religious, socio-cultural and historical heritage 'has never been lost in the lives of the slaves even when languages, family bondages, ethnic belongings unscrupulously destroyed' (Dubois 1905).

The reasons for the spread has to do with the African or black root of the ministry of the Church of God. In Nigeria, there is hardly any church, mainline or African Indigenous churches without Pentecostal or prosperity gospel traits (ed. Fatokun 2007:31-40). The flexibility of the prosperity gospel in adapting to different denominations assisted in the spread.

\section{Conclusion}

After the brief definition, this article has a brief survey of the prosperity preachers, most from Africa and others from Americas and Asia.

This article has demonstrated the African background of the prosperity preaching, by mentioning the strong elements of prosperity in the African worldview, the African indigenous religion and tradition, and culture. The African root of the prosperity gospel in America has also been demonstrated through the historical connection of the African Diaspora with the African continent, especially through William Seymour, who is regarded as the founder or father of Pentecostalism from where prosperity gospel spread throughout the world. As an anonymous African Diaspora said, the slave masters may be able to take them out of the African continent and strip them of their languages and family ties, but they could not take away the African culture and religion in them.

Despite the negative labels on the prosperity gospel, it is difficult to deny that prosperity gospel has given the message of Christ's salvation and hope to Christians, especially the majority of African Christians who are ravaged with diseases, death and poverty. In other words, the prosperity gospel is the good news of the Christ's death and resurrection, which include the good news of healing, prosperity and success. It has encouraged African Christians to remain steadfast with faith in Christ, which is powerful enough to deliver instead of seeking healing, wealth and success from the African traditional divinities because the power of God and Christ is capable of delivering them from sickness, poverty and situations where there is no hope.

The Pentecostalism and prosperity gospel have many implications for African Christians and the church in Africa. Prosperity gospel is transformative and comforting, and adaptable to contexts through the power of Christ's salvation. ${ }^{12}$ Any gospel that does not adapt to context may

12. How 21 scholars including the editor of the book agreed to the fact that prosperity cospelis transormative. It could be called pentecostalisation and the Africanization of Christranity in Africa (Wariboko 2017:138-140). Prosperity the Africanization ( seen as the Africanisation of Christianity in Africa and it is multidirectionally interacting with African traditional religious and African ethos as articulated and experienced in specific communities in Africa (Wariboko 2017:138-140). not be properly understood and may not take root amongst African people. It encourages faith in Christ that is transformative into a material reality in life, which is the potency of faith (Niemandt 2017:203-219; Koch 2009:v-vii). It also motivates African Christians to demonstrate their faith in the God of Israel to perform his miracle again as he did amongst ancient Israelites. Knowing the African background or African root of Pentecostalism and prosperity gospel is gratifying for African Christians because no nation's heritage has been given to other nations like that of Africa. It proves that Christianity is not a foreign religion in Africa as anti-colonialists have argued.

The temptation to use religion as a business is not limited to Pentecostals and prosperity preachers, but a habit that threatens all streams of Christianity (Kruger 2013:336). In other words, the problem of exaggeration and false claim in prosperity gospel preaching is not limited to the Pentecostal or charismatic movement alone, but it is also in all other churches all over the world, and therefore should not be labelled as degradational and degenerated gospel from the orthodox doctrine because it teaches holistic wellbeing like ATR (Kruger 2013:336). The Gospel of Luke teaches categorically that Jesus came to the world to proclaim good news to the poor, freedom for the captives, recovery of sight to the blind and freedom for the oppressed, and therefore prosperity gospel is not an irrelevant phenomenon (Oliver 1999:44-47). Africa needs the message of hope, which the accomplished work of Christ on the cross of Calvary can bring amidst the harsh socio-economic realities.

Finally, Pentecostal and prosperity movements have responsibilities to rewrite their history to reflect accurately its black roots and to formally accept William Joseph Seymour as its founder (Oliver 1999:45-47).

\section{Acknowledgements}

I acknowledge the University of South Africa and especially Prof. Madipoane Masenya of the Department of Biblical and Ancient Studies for the motivation and sponsorship of this article.

\section{Competing interests}

The author declares that no competing interest exists.

\section{Authors' contributions}

D.T.A. is the sole author of this research article.

\section{Ethical considerations}

This article followed all ethical standards for carrying out research without direct contact with human or animal subjects. 


\section{Funding information}

This research received no specific grant from any funding agency in the public, commercial or not-for-profit sectors.

\section{Data availability statement}

The author confirms that the data supporting the findings of this study are available within the article.

\section{Disclaimer}

The views and opinions expressed in this article are those of the author and do not necessarily reflect the official policy or position of any affiliated agency of the author.

\section{References}

Adamo, D.T., 1983, 'The church in Africa and African traditional religious beliefs and practices', Doctor of Religion dissertation, Indiana Christian University, Indianapolis, IN.

Adamo, D.T., 2008, 'Reading Psalm 109 in African Christianity', Old Testament (OTE) 21(3), 575-592.

Adamo, D.T., 2015, 'The missiological implication of African exile/migration (Slavery)', Theologia Viatorum 39(2), 89-111.

African Chapter, Lausanne Theology Working Group, 2008-2009, A statement on prosperity gospel, viewed 03 May 2020, from http://www.lausanne.org/en/ documents/all/twg/1099-a-statement-on-the-prosperity gospel.html.

Anderson, A.H., 2014, An introduction to Pentecostalism: Global charismatic Christianity, Cambridge University Press, Cambridge.

Asamoah-Gyadu, J.K., 2005, African charismatic: Current developments within independent indigenous Pentecostalism in Ghana, Brill Academic, Boston, MA.

Awolalu, J.O., 1979, Yoruba belief and sacrificial rites, Longman, London.

Badejo, D., 1996, Osun Seegesi: The elegant deity of wealth, power and feminity, Africa World Press, Inc., Trenton, NJ.

Barron, B., 1987, The health and wealth gospel: What's going on today in a movement that has shaped the faith of millions? Intervarsity Press, Downers Grove, IL.

Beyers, J., 2010, 'What is religion? An African understanding', HTS 66(1), 1-19. https:// doi.org/10.4102/hts.v66i1.341

Bowler, K., 2013, Blessed: A history of the American prosperity gospel, Oxford University Press, New York, NY.

Bruce, S., 1990, Pray TV: Televangelism in America, Routledge, London.

Burgess, S.M. (ed.), 2006, Encyclopaedia of Pentecostal and Charismatic Christianity, Routledge, New York, NY

Cerillo, A., 1977, 'Interpretative approaches to the history of American Pentecostal origins', Journal of the Society for Pentecostal Studies 29(1), 35-40. https://doi. org $/ 10.1163 / 157007497 \times 00046$

Ceser, W.A. \& Richard, S., 2000, Pentecostalism and the future of the Christian churches: Promises, limitations, challenges, W.B. Eerdmans, Grand Rapids, MI.

Chilongani, D., 2007, 'Prosperity gospel in Africa, African institute for contemporary mission and research', (AICMAR) Bulletin 6(53), 20-25.

Chidester, D., 2009, 'African spirituality and the poverty of western religious experience', in C.W. Du Toit (ed.), African challenges unfolding identity, pp. 97-116, Unisa Press, Pretoria.

Clarke, P.B. (ed.), 2006, Encyclopeadia of new religious movement, Routledge, London.

Coleman, S., 2000, The globalisation of charismatic Christianity: Spreading the gospel of prosperity, Cambridge University Press, Cambridge.

Cox, H., 1993, 'Why God didn't die: A religious renaissance flourishing around the world, Pentecostal Christians leading the way', Nieman Reports 47(2), 3-8.

Dada, O.A., 2001, 'A millionaire through Jesus: II Corinthians 8:9 from the perspective of some Nigerian prosperity preachers', African Journal of Biblical Studies 16(1), $82-90$.

Fatokun, S., 2007, 'The founder of Global Pentecostalism, Parham or Seymour? A historical evaluation', Orita 39(2), 31-40.

Gbotoe, E., 2013, 'Commercialized gospel: A missiological assessment of prosperity gospel', MA (Theology) dissertation, University of Pretoria, Pretoria.

Gbote, E. \& Kgatla, S., 2014, 'Prosperity gospel: A missiological assessment', HTS Teologiese Studies/theological Studies 70(1), a2105. https://doi.org/10.4102/hts. v70i1.3133

Gehman, R.J., 1989, African traditional religion in biblical perspective, Kijabe Printing Press, Kijabe.

Gerloff, R., 1998, 'Pentecostals and the African diaspora', A.H. Anderson (eds.), Pentecostals after a century, global perspectives on a movement in transition, pp. 67-86, Sheffield Academic Press, Sheffield.
Guma, M. \& Milton, L., 1997, An African challenge to the church in the 21st century, Salty print, Cape Town.

Harrell, D.E., 1975, All things are possible: The healing \& Charismatic revivals in modern America, Indiana University Press, Bloomington, IN.

Heuser, A, 2016, 'Charting African prosperity gospel economies', HTS Teologiese Studies/Theological Studies 72(1), a3823. https://doi.org/10.4102/hts.v72i1.3823

Hock, K, 1995, 'Jesus power-super-power!: On the interface between Christian fundamentalism and new Religious movement in Africa', Mission Studies 12(1), 50-60. https://doi.org/10.1163/157338395X00051

Hollinger, D, 1991, 'Enjoying God forever: An historical/sociological profile of the health and wealth gospel in the U.S.A', in P. Gee \& J. Fulton (eds.), Religion and power, decline and growth: Sociological analyses of Religion in Britain, Poland, and the Americas, pp. 53-66, British Sociological Association Sociology of Religion Study Group, London.

Hollenweger, W.J., 1999, 'The black roots of Pentecostalism', in A. Anderson (ed.), Pentecostals after a century; Global perspectives on a movement in transition, pp. 46-47, Sheffield Academic Press, Sheffield.

Horton, M., 1990, The agony of deceit: What some TV preachers are really teaching, Moody Press, Chicago, IL.

Idahosa, B., 1987, I choose to change: The scriptural way to success and prosperity, Highland Books, Crowbrorogh.

Idowu, M.B., 1991, African traditional religion: A definition, Fountain Press, Ibadan.

Kahl, W., 2007, 'Prosperity preaching in West Africa: An evaluation of contemporary ideology from a New Testament perspective', Gluma Bulletin of Theology 2(2), 21-30.

Karenga, M., 1980, Introduction to black studies, Kawaida Publications, Los Angeles, CA.

King, L., 2006, 'Larry King Live', CNN, viewed 22 December 2006, from http:// transcripts.cnn.com/TRANSCRIPTS/0612/22/lkl.01.html.

Koch, B., 2009, 'The prosperity gospel and economic prosperity: Race, class, giving, and voting', Unpublished dissertation, Indiana University, Indianapolis.

Kruger, J.S., 1995, Along edges: Religion in South Africa: Bushmen, Christian, Buddhist, University of South Africa, Pretoria.

Kruger, J.S., Lubbe, G.J. \& Steyn, H.C., 2009, The human search for meaning: A mult religion introduction to the religions of humankind, Van Schaik Publishers, Pretoria.

Kwanteng-Yeboah, J., 2017, 'A reappraisal of prosperity gospel in African Neo-Pentecostal: The potency of multiple modernities paradigm', Master's dissertation, Queen's University, Ontario, Canada.

Lyons, A.P., 1987, 'Magical medicine on television', Journal of Ritual Studies 1(1), 35-40.

Magesa, L., 2002, African religion: The moral traditions of abundant life, Orbis Publishers, Maryknoll, NY

Magezi, V.\& Mazanga, P., 2016, 'Prosperity and health ministry as coping mechanism in the poverty and suffering context of Zimbabwe: A pastoral evaluation and response', In Skriflig 50(1), 1-14. https://doi.org/10.4102/ids.v50i1.2076

Maier, K., 2000, Thishouse has falling: Mid-night in Nigeria, Public Affairs, New York, NY.

Malueke, T.S., 2001, 'Identity and integrity in African theology: A critical analysis', Religion and Theology 8(1), 26-39. https://doi.org/10.1163/157430101X00026

Mbiti, J.S., 1979, Concepts of God in Africa, 5th edn., Society for Promoting Christian Knowledge (SPCK) Publishers, London.

Mbiti, J.S., 1990, African religion and philosophy, 2nd edn., Heinemann, London.

Mende, D., 2019, 'A Biblical analysis of the main teachings of the prosperity gospel, with special reference to the preachers of Hyderabad, India', Journal of Asian Evangelical Theology.23(1), 19-35.

Mumford, D., 2012, Exploring prosperity preaching: Biblical health, wealth, and wisdom, Judson Press, Valley Forge, PA.

Mulrain, G., 1999, 'Hermeneutics within a Caribbean context', in R.S. Sugirtharajah (ed.), Vernacular hermeneutics, pp. 116-132, Sheffield Academic Press, Sheffield.

Nel, M., 2019, 'African background of pentecostal theology: A critical perspective', In die skriflig 53(4), a2418. https://doi.org/10.4102/ids.v53i4.2418

Niemandt, N., 2017, 'The prosperity gospel, the decolonization of theology, and the abduction of missionary imagination', Missionalia 45(3), 203-219. https://doi. org/10.7832/45-3-199

Piper, J., 2007, Prosperity preaching: Deceit and deadly, viewed 06 June 2020, from https://www.desiringgod.org/articles/prosperity-preaching-deceitful-anddeadly.

Olatunji, O., 1984, Features of Yoruba oral poetry, University Press Limited, Ibadan.

Oliver, E., 1999, 'Response to the black roots of Pentecostalism', by W. Hollenweger, in A. Anderson \& W. Hollenbeger (eds.), Pentecostals after a century global perspectives on a movement in transition, Sheffield Academic Press, Sheffield, pp. 45-48.

Olusuyi, O., 2017, The Biblical and African basis of prosperity gospel, A B.A Project, Kogi State University, Anyigba.

Osteen, J., 2004, Your best life now: 7 steps to living at your full potential, Warner Books, New York, NY.

Oyedepo, D., 2005, Exploit of faith, Dominion Publishing, Canaan Land, OH. 
Oyedepo, D., 2006, Winning the war against poverty, Dominion Publishing House, Lagos.

Richardson, A., 1999, 'World Pentecostalism at a crossroads', A. Richardson \& W.J. Hollenweger (eds.), Pentecostals after a century global perspectives on a movement in transition, pp. 24-30, Sheffield Academic Press, Sheffield.

Roberts, O., 1970, The miracle of seed-faith, Oral Robert Ministry, Tulsa, OK.

Sipeyiye, M., 2015, 'Who is on the side of the ancestral spirits? A critical Assessment of the role of African traditional Religions on the Zimbabwean political landscape' in F.H. Chihanda, V.M. Molobi \& I.D. Mothoagae (eds.), African Theological reflections, pp. 125-144, UNISA Press, Pretoria.

Stinton, D., 2004, Jesus of Africa: Voices of contemporary African Christologies, Pauline Publications Africa, Nairobi.

Talbot, P.A., 1926, The people of Southern Nigeria, Oxford University Press, Oxford.

Thomas, J.C., 2012, 'Prosperity preaching: West African traditional belief, or Foreign import?', Ogbomoso Journal of Theology 17(1), 164-172.
Tumbull, J., 2010, 'Prosperity', Oxford advance learner's dictionary, 8th International Student edn., Oxford University Press, Oxford.

Turaki, Y., 1999, Christianity and African gods: A method in theology, Porchefstroomse Universiteitvir Christelike Hoer Onderwys, Potchefstroom.

Van Biema, D. \& Chu, J., 2006, 'Does God want you to be rich?', Times, 18 September pp. 48-56.

Wariboko, N.W., 2015, 'A review of Heuser Andreas book Pastures of plenty: Praying religious scapes of Prosperity Gospel in Africa and beyond', Pentecostal Studies, 16(1), 138-140. https://doi.org/10.1558/ptcs.33404

Westerlund, D., 2009, Global Pentecostalism: Encounters with other religious traditions, I.B. Tauris, London.

Wilmore, G.S., 1986, 'Black Americans in mission: Setting the record straight', International Bulletin of Missionary Research 10(3), July, 98-103.

Wood, V., 1999, 'The Biblical jubilee: The African American experience', in C. Felder (eds.), The Holy Bible, African American Jubilee Edition, pp. 20-25, American Bible Society, New York. 